\title{
Agile Methodology in Theory and Practice an Indian Perspective
}

\author{
${ }^{1}$ Dr. Himanshu Aggarwal , ${ }^{2}$ Ms.Khushdeep Sharma \\ 1, 2 Department of Computer Engineering \\ Punjabi University, Patiala \\ India
}

\begin{abstract}
During the past years, many new software development methodologies were introduced to develop the high quality software in short period of time with minimal costs and within unpredictable changing environment and Agile Methodology is one of them. This paper presents the difference between the agile methodology concepts in reality and in theory. For this data is collected from four small scale industries that are using Agile methodologies concepts during software development and analysis about the practical adoption level of Agile is framed out.
\end{abstract}

Keyword: Agile Software Development, Heavyweight Software Development

\section{INTRODUCTION}

In today scenario software development is expanding and is merging into many diverse fields, and hence becoming more inflexible and complex. Changing and Unpredictable requirements from customers is making it even more difficult. Traditional software development approaches are not able to curb the new changing requirements of the market in the best way, anymore. To solve such problems, new software development approaches are evolved, as agile methodologies which deliver faster, cheaper and better solutions. It includes some modifications to software development processes to make them more efficient, productive and flexible.

\section{BACKGROUND}

Agility is the flexibility of the software to react expeditiously and ability to fit to various changes in its surround. Main motive is to strip away the project heaviness which results when traditional heavyweight software development methodologies are used. Keeping this in mind, a number of software professional individually started using new lightweight software processes and result of their researches leads to set a new methodology called Agile and this term came into existence when seventeen of the developers of the "lightweight" approaches to software development came together in a workshop in early 2001 and they created the Agile Manifesto.

\section{A. Agile Manifesto}

An alternative to heavyweight documentation driven
Software development process came when the representatives from Extreme Programming (XP), Scrum, Crystal Methods, and Feature-Driven Development (FDD) gathered and proposed the Agile values as:

- Individuals and interactions over Processes and tool

- Working software over Comprehensive documentation

- Customer collaboration over Contract negotiation

- Responding to change over following a plan

That is, while there is value in the items on the right, we value the items on the left more". [1]

\section{Proposed Work}

In the proposed system, the exact practical implementation of agile methodology has been figured out with the objectives to be obtained as listed below:

1. To find scope of Agile Methodology in Small Scale IT Industries.

2. To evaluate the usefulness of Agile Practices.

3. Problems encounter while using Agile Practices.

4. Limitation of Heavyweight Methodology.

5. Cost and Quality tradeoff when shifting towards Agile Methodology.

For this four companies has been selected which provides the data for the research to be carried out. The companies have been selected on various parameters which are listed below: 
Dr. Himanshu Aggarwal ,Ms.Khushdeep Sharma," Agile Methodology in Theory and Practice an Indian Perspective”, International Journal of Computer Engineering In Research Trends, Volume 3, Issue 9, September-2016, pp. 476-481

$>$ Industry must deliver IT related products.

$>$ Survey will be conducted on Small Scale Industries.

$>$ Using agile methodology for more than one year.

$>$ Using Software Capability Quality standards.

A questionnaire is framed which consists of questions related to Agile methodology principles, values, process, techniques, dislikes of Agile and heavy weight methodology aspects, tradeoff between quality and cost parameters, limitation of Agile and heavyweight methodology etc. The questions were filled up by project managers, agile coach, business analyst, programmer or developer, designer and tester. A summary of the results and an analysis of the questionnaire have been done with the help of T test implemented in Matlab.

\section{Conclusion}

Result has been evaluated using $\mathrm{T}$ test on the whole collected data to arrive at generalized solution. Also $\mathrm{T}$ test is applied on the occupation of the employee. Basically target is to figured out the agile usage knowledge with respect to project managers, agile coach, business analyst, designer, programmer or developer.

A. Results obtained using T test to arrive at generalized solution::

Table 1.1 Result Evaluation using T test

\begin{tabular}{|c|l|l|}
\hline $\begin{array}{c}\text { Sr. } \\
\text { No }\end{array}$ & \multicolumn{1}{|c|}{ Questions } & Results Obtained \\
\hline 1 & $\begin{array}{l}\text { What type of business or } \\
\text { organization are you } \\
\text { employed in? }\end{array}$ & $\begin{array}{l}\text { Information } \\
\text { Technology }\end{array}$ \\
\hline 2 & $\begin{array}{l}\text { Which Agile Method does } \\
\text { you like the most? }\end{array}$ & Scrum \\
\hline 3 & $\begin{array}{l}\text { Which Agile Technique you } \\
\text { mostly prefer? }\end{array}$ & $\begin{array}{l}\text { Sprints } \\
\text { Meetings }\end{array}$ \\
\hline 4 & $\begin{array}{l}\text { In which phase you typically } \\
\text { use Agile methods? }\end{array}$ & Development Phase \\
\hline 5 & $\begin{array}{l}\text { Which aspect of Agile } \\
\text { Methodology do you dislike } \\
\text { the most for different kind } \\
\text { of software development? }\end{array}$ & $\begin{array}{l}\text { Less Management } \\
\text { Control }\end{array}$ \\
\hline 6 & $\begin{array}{l}\text { Which aspect of Heavy } \\
\text { Methodology do you dislike } \\
\text { the most for different kind } \\
\text { of software development? }\end{array}$ & Comprehensive \\
\hline 7 & $\begin{array}{l}\text { How do you believe the cost } \\
\text { of employing Aglanning } \\
\text { Methodologies compares } \\
\text { with Heavyweight } \\
\text { Methodologies for software } \\
\text { development process? }\end{array}$ & $\begin{array}{l}\text { Low Decrease in } \\
\text { Costs }\end{array}$ \\
\hline 8 & $\begin{array}{l}\text { Do you believe that taking } \\
\text { on of Agile Methodologies } \\
\text { rather than Heavyweight } \\
\text { effect on Software Quality? }\end{array}$ & $\begin{array}{l}\text { High Increase in } \\
\text { Quality }\end{array}$ \\
\hline 9 & What do you believe is the & Agile \\
\hline
\end{tabular}

\begin{tabular}{|c|l|ll|}
\hline & $\begin{array}{l}\text { most suitable methodology } \\
\text { for different kinds of } \\
\text { software development? }\end{array}$ & \\
\hline 10 & $\begin{array}{l}\text { What do you think are the } \\
\text { limitation of Agile } \\
\text { Methodology? }\end{array}$ & $\begin{array}{l}\text { Requirement } \\
\text { Training }\end{array}$ \\
\hline
\end{tabular}

Results specify that the Scrum is the most used Agile Method in all the four companies and Sprints and Meetings is the most preferred technique. Mainly the Agile Methodology is used in Development Phase. Agile Methodology results in Low decrease in Costs and High Increase in Quality as Compared to Heavy weight Methodologies. Comprehensive Up front planning is the major drawback of heavy weight methodologies. Requirement of training and less management control is the most dislikes of Agile.

Most Used Agile Method: Scrum

\section{Various Agile Method Usage Percentage}

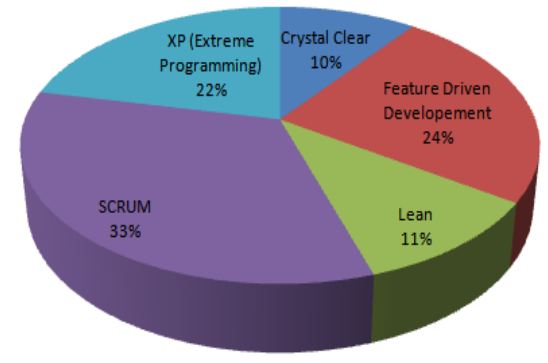

Figure 1: Agile Methods distribution

Most Used Agile Technique: Sprints and Meetings

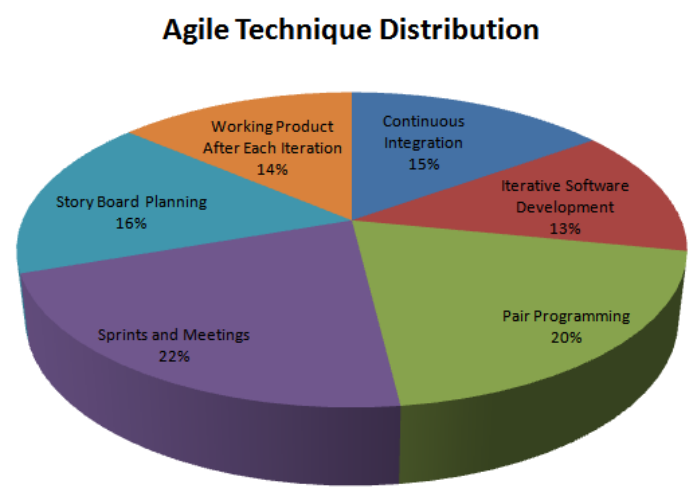

Figure 2: Agile Techniques distribution

Most dislike aspect of heavyweight methodology: Comprehensive upfront planning. 
Dr. Himanshu Aggarwal ,Ms.Khushdeep Sharma," Agile Methodology in Theory and Practice an Indian Perspective", International Journal of Computer Engineering In Research Trends, Volume 3, Issue 9, September-2016, pp. 476-481

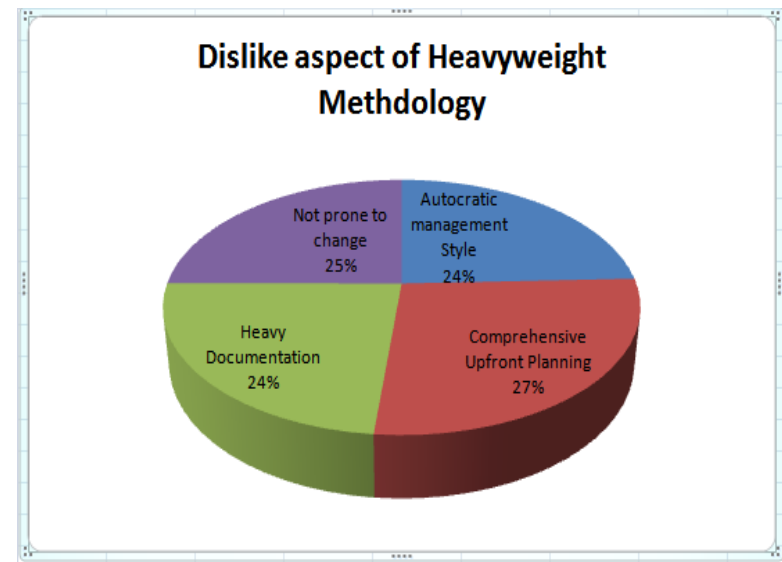

Figure 3: Dislikes distribution of heavyweight methodology

Most Dislike aspect of Agile Methodology: Less Management Control

Dislike aspect of Agile Methodology

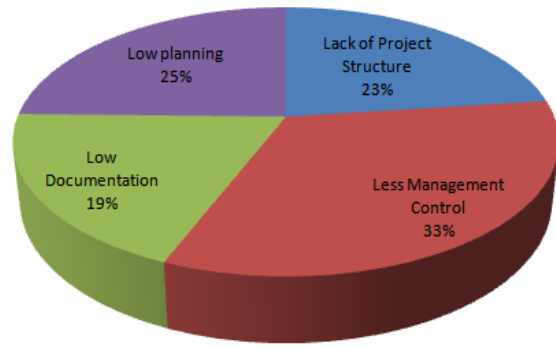

ure 4: Dislike aspect of Agile Methodology.

Limitation of Agile Methodology: Requirement of Training.

Limitation of Agile Methdology

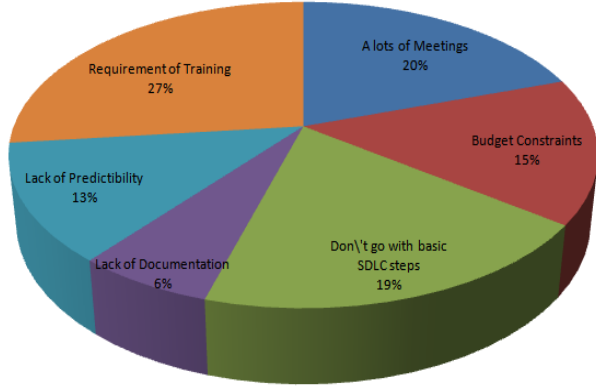

Figure 5: Limitation of Agile Methodology.
B. Results obtained using $T$ test on Occupation of Employee:

Table 1.2 Result Evaluation using $T$ test on Project Manager Occupation

\begin{tabular}{|c|c|c|}
\hline $\begin{array}{l}\text { Sr. } \\
\text { No }\end{array}$ & Questions & Project Managers \\
\hline 1 & $\begin{array}{l}\text { Up to what extent you are } \\
\text { using Agile Methods? }\end{array}$ & Large Numbers \\
\hline 2 & $\begin{array}{l}\text { Which Agile Method do you } \\
\text { like the most? }\end{array}$ & Scrum \\
\hline 3 & $\begin{array}{l}\text { Which Agile Technique you } \\
\text { mostly prefer? }\end{array}$ & $\begin{array}{ll}\text { Story } & \text { Board } \\
\text { Planning } & \end{array}$ \\
\hline 4 & $\begin{array}{l}\text { In which phase you typically } \\
\text { use Agile methods? }\end{array}$ & System Analysis \\
\hline 5 & $\begin{array}{l}\text { Which aspect of Agile } \\
\text { Methodology do you dislike } \\
\text { the most for different kind of } \\
\text { software development? }\end{array}$ & $\begin{array}{l}\text { Lack of project } \\
\text { Structure }\end{array}$ \\
\hline 6 & $\begin{array}{l}\text { Which aspect of Heavy } \\
\text { Methodology do you dislike } \\
\text { the most for different kind of } \\
\text { software development? }\end{array}$ & $\begin{array}{l}\text { Autocratic } \\
\text { Management Style }\end{array}$ \\
\hline 7 & $\begin{array}{l}\text { How do you believe the cost } \\
\text { of employing Agile } \\
\text { Methodologies compares with } \\
\text { Heavyweight Methodologies } \\
\text { for software development } \\
\text { process? }\end{array}$ & $\begin{array}{l}\text { Low Decrease in } \\
\text { Costs }\end{array}$ \\
\hline 8 & $\begin{array}{l}\text { Do you believe that taking on } \\
\text { of Agile Methodologies } \\
\text { rather than Heavyweight } \\
\text { methodologies have any } \\
\text { effect on Software Quality? }\end{array}$ & $\begin{array}{l}\text { High Increase in } \\
\text { Quality }\end{array}$ \\
\hline 9 & $\begin{array}{l}\text { What do you believe is the } \\
\text { most suitable methodology } \\
\text { for different kinds of software } \\
\text { development? }\end{array}$ & Agile \\
\hline 10 & $\begin{array}{l}\text { What do you think are the } \\
\text { limitation of Agile } \\
\text { Methodology? }\end{array}$ & $\begin{array}{l}\text { Requirement } \\
\text { Training }\end{array}$ \\
\hline
\end{tabular}

According to T Test Results, All the Project Managers of all the four companies are using Agile Methodology in large number of projects with Scrum as most used method and Story Board Planning technique as most preferred technique. Switching towards Agile Methodology results into high increase in quality and low decrease in costs as compared to Heavy Weight Methodologies. There is tremendous need of training to understand the principles behind Agile Methodology.

Table 1.3 Result Evaluation using T test on Agile Coach Occupation

\begin{tabular}{|l|l|l|}
\hline $\begin{array}{l}\text { Sr. } \\
\text { No }\end{array}$ & Questions & Agile Coach \\
\hline 1 & $\begin{array}{l}\text { Up to what extent you are } \\
\text { using Agile Methods? }\end{array}$ & Just Started \\
\hline
\end{tabular}


Dr. Himanshu Aggarwal ,Ms.Khushdeep Sharma," Agile Methodology in Theory and Practice an Indian Perspective", International Journal of Computer Engineering In Research Trends, Volume 3, Issue 9, September-2016, pp. 476-481

\begin{tabular}{|l|l|l|}
\hline 2 & $\begin{array}{l}\text { Which Agile Method do you } \\
\text { like the most? }\end{array}$ & Lean \\
\hline 3 & $\begin{array}{l}\text { Which Agile Technique you } \\
\text { mostly prefer? }\end{array}$ & $\begin{array}{l}\text { Continuous } \\
\text { Integration }\end{array}$ \\
\hline 4 & $\begin{array}{l}\text { In which phase you typically } \\
\text { use Agile methods? }\end{array}$ & Testing \\
\hline 5 & $\begin{array}{l}\text { Which aspect of Agile } \\
\text { Methodology do you dislike } \\
\text { the most for different kind } \\
\text { of software development? }\end{array}$ & Low Planning \\
\hline 6 & $\begin{array}{l}\text { Which aspect of Heavy } \\
\text { Methodology do you dislike } \\
\text { the most for different kind } \\
\text { of software development? }\end{array}$ & Documentation \\
\hline 7 & $\begin{array}{l}\text { How do you believe the cost } \\
\text { of employing Agile } \\
\text { Methodologies compares } \\
\text { with Ho Effect } \\
\text { Methodologies for software } \\
\text { development process? }\end{array}$ & \\
\hline 8 & $\begin{array}{l}\text { Do you believe that taking } \\
\text { on of Agile Methodologies } \\
\text { rather than Heavyweight } \\
\text { methodologies have any } \\
\text { effect on Software Quality? }\end{array}$ & \\
\hline 9 & $\begin{array}{l}\text { What do you believe is the } \\
\text { most suitable methodology } \\
\text { for different kinds of } \\
\text { software development? }\end{array}$ & Not Sure \\
\hline 10 & $\begin{array}{l}\text { What do you think are the } \\
\text { limitation of } \\
\text { Methodology? Agile }\end{array}$ & A lots of meetings \\
\hline According to T test Results, All the & \\
\hline
\end{tabular}

According to T test Results, All the Agile Coaches have just started using the Agile Methodology with Lean and Continuous Integration as most likely method and preferred technique respectively. All the Agile Coaches used Agile Methodology mainly in Testing Phase. T test results specify that there is no effect on Software Quality and Cost when employing Agile Methodologies as compared to Heavy weight Methodologies according to Agile Coaches. Low Planning and lots of meetings are the dislikes of Agile Methodologies.

Table 1:4 Result Evaluation using T test on Business Analyst Occupation

\begin{tabular}{|l|l|l|}
\hline $\begin{array}{l}\text { Sr. } \\
\text { No }\end{array}$ & Questions & Business Analyst \\
\hline 1 & $\begin{array}{l}\text { Up to what extent you are } \\
\text { using Agile Methods? }\end{array}$ & $\begin{array}{l}\text { Majority of } \\
\text { Projects }\end{array}$ \\
\hline 2 & $\begin{array}{l}\text { Which Agile Method does } \\
\text { you like the most? }\end{array}$ & $\begin{array}{l}\text { Extreme } \\
\text { Programming }\end{array}$ \\
\hline 3 & $\begin{array}{l}\text { Which Agile Technique you } \\
\text { mostly prefer? }\end{array}$ & $\begin{array}{l}\text { Iterative Software } \\
\text { Development }\end{array}$ \\
\hline 4 & $\begin{array}{l}\text { In which phase you typically } \\
\text { use Agile methods? }\end{array}$ & Testing \\
\hline 5 & $\begin{array}{l}\text { Which aspect of Agile } \\
\text { Methodology do you dislike } \\
\text { the most for different kind of } \\
\text { software development? }\end{array}$ & Low Planning \\
\hline
\end{tabular}

\begin{tabular}{|l|l|ll|}
\hline 6 & $\begin{array}{l}\text { Which aspect of Heavy } \\
\text { Methodology do you dislike } \\
\text { the most for different kind of } \\
\text { software development? }\end{array}$ & $\begin{array}{l}\text { Autocratic } \\
\text { Management Style }\end{array}$ \\
\hline 7 & $\begin{array}{l}\text { How do you believe the cost } \\
\text { of employing Agile } \\
\text { Methodologies compares } \\
\text { with High Decrease in } \\
\text { Methodologies for software } \\
\text { development process? }\end{array}$ & $\begin{array}{l}\text { Costs } \\
\text { Do you believe that taking on } \\
\text { of Agile Methodologies } \\
\text { rather than Heavyweight } \\
\text { methodologies have any } \\
\text { effect on Software Quality? }\end{array}$ & Quality Increase in \\
\hline 9 & $\begin{array}{l}\text { What do you believe is the } \\
\text { most suitable methodology } \\
\text { for different kinds of } \\
\text { software development? }\end{array}$ & Agile \\
\hline 10 & $\begin{array}{l}\text { What do you think are the } \\
\text { limitation of Agile } \\
\text { Methodology? }\end{array}$ & Requirement \\
Training
\end{tabular}

According to $\mathrm{T}$ test results, Business Analysts are using Agile Methodology in majority of projects with Extreme Programming and Iterative Software Development as most likely method and preferred technique respectively. They used the agile principles mainly in testing phase. According to them, there is high decrease in costs and high increase in quality when switch to Agile Methodology as compared to Heavy Weight Methodology. Requirement of training and Low planning are major dislikes of Agile Methodology.

Table 1.4 Result Evaluation using $T$ test on Designer Occupation

\begin{tabular}{|c|c|c|}
\hline $\begin{array}{l}\text { Sr. } \\
\text { No }\end{array}$ & Questions & Designers \\
\hline 1 & $\begin{array}{l}\text { Up to what extent you are } \\
\text { using Agile Methods? }\end{array}$ & Majority of Projects \\
\hline 2 & $\begin{array}{l}\text { Which Agile Method does } \\
\text { you like the most? }\end{array}$ & $\begin{array}{l}\text { Extreme } \\
\text { Programming }\end{array}$ \\
\hline 3 & $\begin{array}{l}\text { Which Agile Technique you } \\
\text { mostly prefer? }\end{array}$ & $\begin{array}{l}\text { Working Product } \\
\text { after each iteration }\end{array}$ \\
\hline 4 & $\begin{array}{l}\text { In which phase you typically } \\
\text { use Agile methods? }\end{array}$ & Development \\
\hline 5 & $\begin{array}{l}\text { Which aspect of Agile } \\
\text { Methodology do you dislike } \\
\text { the most for different kind } \\
\text { of software development? }\end{array}$ & $\begin{array}{l}\text { Less Management } \\
\text { Control }\end{array}$ \\
\hline 6 & $\begin{array}{l}\text { Which aspect of Heavy } \\
\text { Methodology do you dislike } \\
\text { the most for different kind } \\
\text { of software development? }\end{array}$ & $\begin{array}{l}\text { Comprehensive } \\
\text { Upfront Planning }\end{array}$ \\
\hline 7 & $\begin{array}{l}\text { How do you believe the cost } \\
\text { of employing Agile } \\
\text { Methodologies compares } \\
\text { with Heavyweight } \\
\text { Methodologies for software }\end{array}$ & $\begin{array}{l}\text { High Decrease in } \\
\text { Costs }\end{array}$ \\
\hline
\end{tabular}


Dr. Himanshu Aggarwal ,Ms.Khushdeep Sharma," Agile Methodology in Theory and Practice an Indian Perspective”, International Journal of Computer Engineering In Research Trends, Volume 3, Issue 9, September-2016, pp. 476-481

\begin{tabular}{|l|l|ll|}
\hline & development process? & & \\
\hline 8 & $\begin{array}{l}\text { Do you believe that taking } \\
\text { on of Agile Methodologies } \\
\text { rather than Heavyweight } \\
\text { methodologies have any } \\
\text { effect on Software Quality? }\end{array}$ & $\begin{array}{l}\text { High Increase in } \\
\text { Quality }\end{array}$ \\
\hline 9 & $\begin{array}{l}\text { What do you believe is the } \\
\text { most suitable methodology } \\
\text { for different kinds of } \\
\text { software development? }\end{array}$ & Agile \\
\hline 10 & $\begin{array}{l}\text { What do you think are the } \\
\text { limitation of Agile } \\
\text { Methodology? }\end{array}$ & Requirement \\
Training
\end{tabular}

$\mathrm{T}$ test results specify that the Designers are using Agile Methodology in majority of projects with Extreme Programming as most likely agile method and working product after each iteration as mostly preferred technique. Designers use Agile Concepts mainly in Development phase. According to them there is high Decrease in Costs and High Increase in Quality when switching towards Agile with respect to Heavyweight Methodology. Less Management Control and Requirement of training are main drawbacks of Agile

\section{Table 1.5 Result Evaluation using T test on Programmer} Occupation

\begin{tabular}{|l|l|l|}
\hline $\begin{array}{l}\text { Sr. } \\
\text { No }\end{array}$ & Questions & $\begin{array}{l}\text { Programmer } \\
\text { Developer }\end{array}$ \\
\hline 1 & $\begin{array}{l}\text { Up to what extent you are } \\
\text { using Agile Methods? }\end{array}$ & Small Numbers \\
\hline 2 & $\begin{array}{l}\text { Which Agile Method does } \\
\text { you like the most? }\end{array}$ & $\begin{array}{l}\text { Extreme } \\
\text { Programming }\end{array}$ \\
\hline 3 & $\begin{array}{l}\text { Which Agile Technique you } \\
\text { mostly prefer? }\end{array}$ & Pair Programming \\
\hline 4 & $\begin{array}{l}\text { In which phase you typically } \\
\text { use Agile methods? }\end{array}$ & Development \\
\hline 5 & $\begin{array}{l}\text { Which aspect of Agile } \\
\text { Methodology do you dislike } \\
\text { the most for different kind } \\
\text { of software development? }\end{array}$ & Low Planning \\
\hline 6 & $\begin{array}{l}\text { Which aspect of Heavy } \\
\text { Methodology do you dislike } \\
\text { the most for different kind } \\
\text { of software development? }\end{array}$ & Deavy \\
\hline 7 & $\begin{array}{l}\text { How do you believe the cost } \\
\text { of employing Agile } \\
\text { Methodologies compares } \\
\text { with } \\
\text { Methodologies for software } \\
\text { development process? }\end{array}$ & \begin{tabular}{l} 
Low Decrease in \\
Costs \\
\hline 8 \\
Do you believe that taking \\
on of Agile Methodologies \\
methodologies have any \\
effect on Software Quality?
\end{tabular} \\
\hline 9 & $\begin{array}{l}\text { What do you believe is the } \\
\text { most suitable methodology }\end{array}$ & $\begin{array}{l}\text { High Increase in } \\
\text { Quality }\end{array}$ \\
\hline
\end{tabular}

\begin{tabular}{|l|l|l|}
\hline 10 & $\begin{array}{l}\text { for different kinds of } \\
\text { software development? }\end{array}$ & \\
\hline $\begin{array}{l}\text { What do you think are the } \\
\text { limitation of Agile } \\
\text { Methodology? }\end{array}$ & A lots of meetings \\
\hline
\end{tabular}

Based on the collected data and results obtained from $\mathrm{T}$ test, Programmers are using Agile Methods in small numbers. Most likely method is Extreme Programming and preferred technique as Pair Programming. Programmers mainly use the agile concepts during Development phase. Lots of meetings and low planning are major drawback of Agile.

\section{References}

[1] Beck, Kent; et al. (2001). "Manifesto for Agile Software Development" Agile Alliance retrieved 14 June, 2010

[2] Manish et al, "A Detail Study of Agile Software Development with Extreme Programming".International Journal of Advanced Research in Computer Science and Software Engineering 5(10), October- 2015, pp. 719-725.

[3] Leo R. Vijayasarathy, "AGILE SOFTWARE DEVELOPMENT: A SURVEY OF EARLY ADOPTERS". Journal of Information Technology Management, 2008.

[4] Nayab Zya, "AGILE METHODOLOGIES IN SOFTWARE DEVELOPMENT". International Journal of Engineering Technology, Management and Applied Sciences, 2014.

[5] Sakshi Sachdeva, "Agile Methodologies", 2016", International Journal of Computer Science and Information Technologies, Vol. 7 (1) , 2016, 40-44.

[6] MALIK HNEIFe, "Review of Agile Methodologies in Software Development". International Journal of Research and Reviews in Applied Sciences, 2009.

[7] Dan Turk, "Limitations of Agile Software Processes", Third International Conference on Extreme Programming and Flexible processes in Software Engineering, XP 2002, May 26-30, Alghero, Italy, pg 43-46, 2002.

[8] Richard Downs, "Challanges of Migration to Agile Methodologies", COMMUNICATIONS OF THE ACM May 2005/Vol. 48, No. 5

[9] Bjørnar Tessem, "Experiences in Learning XP Practices". Springer-Verlag Berlin Heidelberg 2003.

[10] Sonia Thakur, "Role of Agile Methodology in Software Development." IJCSMC, Vol. 2, Issue. 10, October 2013, pg.86 - 90 
Dr. Himanshu Aggarwal ,Ms.Khushdeep Sharma," Agile Methodology in Theory and Practice an Indian Perspective”, International Journal of Computer Engineering In Research Trends, Volume 3, Issue 9, September-2016, pp. 476-481

[11] IEEE Standards Collection: Software Engineering, I. S. 610.12-1990, 1993.

[12] W. W. Royce, "Managing the development of large software systems: concepts and techniques," presented at the Proceedings of the 9th international conference on Software Engineering, Monterey, California, United States, 1987.

[13] B. W. Boehm, "A Spiral Model of Software Development and Enhancement," Computer, vol. 21, pp. 61-72, 1988.

[14] R. S. Pressman, Software Engineering: A Practitioner's Approach, 6 ed.: McGraw - Hill International Edition, 2005.

[15] (2001). Manifesto for Agile Software Development. Available: www.agilemanifesto.org 